\title{
THE METAPHORIZATION PHENOMENON IN THE ENGLISH LITERATURE TEXTS. ACTUALIZATION OF THE TIME CONCEPT THROUGH THE METAPHORICAL REALIZATION PROCESS
}

\begin{abstract}
This article is a result of the analysis of metaphorization process and actualization of the TIME concept in the English literature texts. The analysis has been made from different perspectives such as: historical, lexical and semantic. All the results of the article are closely related to our dissertation and based on many scientific works dedicated to the similar linguistic topics.

Purpose. The purpose of the article is a more precise study of the TIME concept and its metaphorization in the English literature texts. It is very important to understand the historical formation of the process as well as its correlation with lexical and semantic aspects of the linguistic.

Methods. The first method of the research is the comparative analysis of different linguists' statement about such a phenomenon as metaphor or metaphorization. The second method is the descriptive analysis of the historical background of the TIME concept formation. The third method is the analysis of the English literature texts in order to find some lexical, semantic, stylistic, pragmatic, syntactic, linguistic and psycholinguistic patterns for the TIME concept metaphorization in this kind of texts.

Results. Specific metaphor properties are the reason why a very important role in a language is dedicated to the metaphor. Language embodiment of new concepts and a creation of new linguistic manners is a direct consequence of the metaphorization process. Certain linguistic forms are a place of a realization of cognitive reality images. These images are based on a metaphorical transference.

The development of the TIME concept part named as time calculation had started in early English period (XIV - XV centuries). The TIME concept has been
\end{abstract}


metaphorically realized very differently. The metaphorization depends on the period of the English history. Modern metaphorical realization of the TIME concept has changed many times but the basic metaphorical associations remained nondeformed.

There are prepositions which classified by the agentic / non-agentic feature. It's been made in order to understand time properties and in order to find correlation between the TIME concept and other aspects of the textual reality. The analysis of the chosen material has led to the distinction of five predicate groups such as: activity, location, status, quality and process. The classification of the prepositions was made in the research. They were distinguished according to the predicates. As a result models of the TIME concept description have been made. It proofs the fact that the TIME concept might be realized as the agentive, objective and dative. The using of the 'time' lexeme as a living initiator of the action is syntactically reasoned. This action causes the personification of time in the English culture.

KEYWORDS: metaphor, metaphorization, metaphorical realization, the TIME concept, English literature

\section{INTRODUCTION}

It's a well-known fact that the metaphorization process is a very peculiar phenomenon which usually can be found in literature texts. A great number of authors use metaphorization to emphasize some concepts in their poems, novels, fairy tales, short stories etc. One of the most interesting concepts that can be distinguished in the English literature is the TIME concept. Time has been the main subject of interest of many writers. And each writer has tried to invent their own personal and unique metaphors in order to represent the TIME concept in the most outstanding and memorable manner. There have been a lot of attempts to realize that intentions throughout history. As a result a huge variety of the TIME concept representations in literature texts exist nowadays. And the metaphorical realization is the most important one.

Purpose: The purpose of the article is a more precise study of the TIME concept and its metaphorization in the English literature texts. It is very important to understand the historical formation of the process as well as its correlation with lexical and semantic aspects of the linguistic.

Methods: The first method of the research is the comparative analysis of different linguists' statement about such a phenomenon as metaphor 
or metaphorization. The second method is the descriptive analysis of the historical background of the TIME concept formation. The third method is the analysis of the English literature texts in order to find some lexical, semantic, stylistic, pragmatic, syntactic, linguistic and psycholinguistic patterns for the TIME concept metaphorization in this kind of texts.

\section{THE FUNDAMENTAL UNDERSTANDING OF THE METAPHORICAL REALIZATION PROCESS}

For a very long period of time many, researchers paid attention to such a phenomenon as a metaphor. „A metaphor is using of a word or a phrase in figurative meaning which is based on similarity, comparison, analogy as well as a word or a phrase which has been used for that matter" (Literaturnaya entsiklopediya, 2018). This phenomenon takes a very important place in the theory of stylistic, pragmatic, syntactic, semantic and psycholinguistic researches.

Problems of the metaphorical functioning and the metaphorization process are the subject of many scientific works. "Metaphorization is the creation of a verbal image by means of a metaphor. The lexical metaphorization as a stylistic matter deeply absorbs all the functional styles of modern literary speech. The metaphorization to a great extent stylistically enriches all the speech in various spheres of its functioning" (Shevchenko, 2010, pp. 354). "Metaphorization is an extension of the semantic volume of lexemes due to the appearance of their figurative meanings and the enhancement of its expressive properties" (Karpilovs'ka, 2010, pp. 29). "Metaphorization is an extension of the content volume of the word by creating figurative meanings in it and enhancing its expressive ones". (Nelyubin, 2003, pp. 162). "Metaphorization is the process of such interaction of the offered essences and operations which leads to obtaining of new knowledge about the world and knowledge about their speech. The metaphorization is characterized by adding of the already known reality features which are reflected in the meaning to a new concept" (Teliya, 1988, pp. 71).

New problems and questions about studying of the metaphorization process and the metaphor phenomenon appear in linguistic science every day. According to this fact it is possible to say that the very essence of the 
metaphor isn't analyzed enough nowadays. This phenomenon may be explained figuratively. "Any speech is a labyrinth of many trails. You go from one side and you know where you are; you come to the same place from the other side and you don't know where you are and where to go next". This statement is a proof of the actual need in searching ways of metaphorical nature explanation, its functional variety, metaphorical mechanisms and other aspects that is related to it.

A metaphor is considered to be a linguistic phenomenon which happens to be in a certain relation with the existence manner in a text world. "A metaphor is not so much a reduced comparison, but an implicit opposition. The cognitive metaphor is directed primarily at the achievement of epistemological goals. From the means of creating an image a metaphor becomes a manner of contents forming. A lack of those contents in language result this kind of forming" (Arutyunova, 1990, pp. 23). "A metaphor is represented in a substitutional paradigm as a word (lexeme, concept, definition) replacement with other word (lexeme, concept, definition)" (Yeshchenko, 2001, pp. 85).

The speech and cognition are not the frames that limit the sphere of a metaphor using. That's caused by the peculiar effect of a metaphor. The effect extends at the human outlook and understanding of being. "A metaphor is a semantic process. According to the process the form of a linguistic unit or design of a language category is transferred from one object of designation to another. The transfer is based on a certain similarity between these objects when they display in the speaker's mind" (Rusanivs'kyy, 2004, pp. 421-422). "A metaphor in lingvo-synergy is a certain equivalent of probabilistic cognition methods" (Batsevych, 2009, pp. 56).

A metaphor might be named as a manner of knowledge realization in a verbal form and as an expression of everyday conceptual implementation. "A metaphor is one of the main tropes. It's a word or word-combination which reveals the essence and the characteristics of a certain phenomenon through a transfer of similar features and properties of another phenomenon. At the same time literal features combine with figurative ones" (Lesyn, 1982, pp. 241). In other words a metaphor creates some kind of an associative field. The field is the place where the metaphor is a means for receiving of 
new information about a text world. The receiving process is based on the variety of symbols and images which can be found in the text. Associations occur in consumers' mind as a result of the process. They are a representation of a peculiar reflection of a conceptual world model. That model acquires pragmatic orientation and anthropocentric interpretation due to a language.

Specific metaphor properties are the reason why a very important role in a language is dedicated to the metaphor. "A metaphor is a language phenomenon that has a cognitive background. It is a using of a language sign of one conceptual sphere for definition of the other. This process is caused by the associations of similarity or contrast. A conceptual metaphor is using of a language sign of one concept for defining the other. The defining process is stable and it's fixed in language, cultural ethnic tradition as well as in persons' thinking. It suggests an understanding the essence of the signified object through an analogy" (Kravets', 2012, pp. 189). It is natural for a metaphor to have an ability of events conceptualization, structuralization of the events perception and self-interpretation. A metaphor has strategic and cognitive senses. Language embodiment of new concepts and a creation of new linguistic manners is a direct consequence of the metaphorization process. Certain linguistic forms are a place of a realization of cognitive reality images. These images are based on a metaphorical transference. An event or a subject influenced by metaphorization process is a source or target domain. A source domain contains all the concepts which used for precise comprehension of the event or the subject. A target domain and a source domain might relate to different functional domains or taxonomic domains. The latter case is usually characterized by missing correlation with a pragmatic function.

"A metaphor is a literary manner. Its function is a figurative using of a word or word-combination based on analogy, similarity or comparison as well as words or word-combinations used that way" (Yaremenko, 1999, pp. 462). The methods of nominating homogeneous concepts through metaphors based on similar associations are defined in the language through a conceptual metaphor. As a result, metaphors cover entire ideographic fields. System projecting of the source domain structure into the structure of the target domain causes the creation of a metaphor. At the same time a process of different situations absorption by the source domain happens 
very often. The situations, scenes and events of the process are identified as gained experience. One of the defining features of conceptual domains is their dissimilarity with each other. This kind of dissimilarity is a result of the variety of their development degree.

\section{THE HISTORICAL, LEXICAL AND SEMANTIC APPROACHES TO THE TIME CONCEPT METAPHORIZATION IN ENGLISH LITERATURE}

The development of the part named as time calculation had started in early English period (XIV - XV centuries). Due to the lack of widespread using of clocks time calculation was done according to the ecclesiastical understanding of time. There were eight time intervals and each of them had its name. These included such as:

1) "matin" - around midnight;

2) "laudes" - three o'clock in the night;

3) "prime" - six o'clock in the morning;

4) "undern", "terce" - nine o'clock in the morning;

5) "sexte" - at noon;

6) "non" - three oclock in the afternoon;

7) "vesper" - six o'clock in the evening;

8) "compline" - nine o'clock in the evening.

At a certain stage of the early English language development, the indication of the exact time started to appear, for instance:

"When? What time did you see it? - About Twelve of the Clock" (Kytö, M., Walker, T.M.)

“...at twelue a clocke you parted from my house, And now tis morning, and new strucken seuen. Seuen houres thou staidst from me, why didst thou so?" (Kytö, M., Walker, T.M.)

"The least denominative part of time is a minute, the greatest integer being a year" [Cocker, 1736, pp. 51).

At the initial stage of the TIME concept development $t$ he dates could be denoted by the names of the holidays. For example: 
"She swore then two or three days after Michaelmas Day"

(Kytö, M., Walker, T.M.)

"Cut off the bough about All-Hallowtide, in the bare place, and set it in the ground, and it will grow to be a fair tree in one year" (Johnson, 1755).

In addition to these timestamps the exact dates were used as well: "beeing taken the 29. of March". A year was designated by numbers or peripherally: "in the 31. yeere of the raigne of Our Soueraigne Lady Elizabeth".

The representation of the TIME concept can be related to a certain historical period or a well-known personality as a symbol of one or another era. For instance:

"Again, a collapse followed, the Second Intermediate Period, followed by the New Kingdom, swiftly developing into the age of grandeur we associate with Rameses II and Tutankhamen, and Egyptian art continued until it was absorbed into the art of the Greco-Roman world" (Davies, 2008-).

"Apart from the sea and its attendant attractions, there is a wealth of elegant Georgian and Victorian architecture"

(British National Corpus).

"The scholars of the Renaissance courts studied in depth the philosophy and dictates of classical authors and applied their knowledge to the education of courtiers, so that they would act and behave correctly in the new society" (British National Corpus).

A definition of time can be realized through historical dates mentioned in the text of literature discourse, for example:

"An old man / ... / and walks off home / to sip a single cup of tea in a rented room / that smells like 1932" (Choyce, L).

The term "spring" has a separate definition in the Middle English conceptualization of time. It was distinguished among others and was considered as a separate season. According to this fact there was a clear distinction in speech. For instance: 
"My Lord, about the end of the Spring, or beginning of Summer, as I remember..." [Kytö M., Walker T.M. A Corpus of English Dialogues 1560 1760. URL: https://www. sketchengine.co.uk/corpusenglish-dialoguеs/ (дата обращения: 20.04.2016)].

"...one day about the latter end of winter or beginning of the spring 1677-8, Edmund Appelby was drinking pretty briskly..."

[Kytö M., Walker T.M. A Corpus of English Dialogues 15601760.

URL: https://www. sketchengine.co.uk/corpus-english-dialogues/

(дата обращения: 20.04.2016)].

An interesting feature of the Middle English time representation is that summer was the next season after winter, for instance:

"After wynter comep somer, and after euene comep day"

(Corpus of Middle English Prose and Verse).

According to the classification May was considered the first summer month, for example:

"After wynter foloweth grene May"

(Corpus of Middle English Prose and Verse).

A part of the "Time image" could be found in the literature of the Early English period. The TIME concept was represented as a resource or some kind of value. It was understood as something that could be alive. The time conceptualization as a resource actualized through an English verb "to spend" and its synonyms. For instance:

"If they will barter away their time, methinks they should at least have some ease in exchange" (Johnson, 1755).

"Going from house to house, tatlers and busybodies, are the canker and rust of idleness, as idleness is the rust of time" (Johnson, 1755).

"But tedious waste of time, to sit and hear so many hollow compliments and lies..." (Johnson, 1755).

This period of time was perceived by the authors as something priceless, for example:

"Throw not away this precious time, a Minute now is inestimable" (Shadwell, 1736, pp. 50).

"The time too precious now to waste" (Swift, 1840, pp. 301). 
The TIME concept is conceptualized in the works of William Shakespeare very clearly. His works are characterized by the metaphorical realization of time. Time is shown like a living object. The texts of the writer are full of many variations of personification such as: verbose, adjective, and substantive. The verbose personification is characterized by an interesting process. The process involves a special using of the subject for definition a non-living object with the verbs which are common for living objects. For instance:

"I wasted time, and now doth time waste me"

(Shakespeare, 2003, pp. 88).

This type of personification is not very usual for literature texts. William Shakespeare used an adjective personification not too often as well. As a rule it might be identified by some rare word-combinations, for example:

“... never-resting time leads summer on" (Shakespeare, 1988, pp. 112).

A substantive type of time personification can be divided on two kinds. The first one is a nomination of time as a living being.

"... old Time the clock-setter, that bald sexton Time", "Time's the king of men", "O Time, thou tutor 'o", "Time is the old justice", "... that old common arbitrator, Time" (Shakespeare, 2010, pp. 236).

The lexical unit 'Time' may be found in Shakespeare's literary works. That word starts with a capital letter all the time. That's the author's method to emphasis a personification.

The second kind of the substantive personification is a realization of the anthropomorphic features in time. A huge variety of human characteristics are concentrated in a lexeme 'time'. As a result it is possible to differentiate such word-combinations as: "Time's fell hand", "the inaudible and noiseless foot of Time", "the tooth of time" etc. Anthropomorphization of time is manifested in the fact that time is able to use certain subjects: "Time's pencil", "Time hath, my lord, a wallet at his back" etc.

The most common metaphorization type is metaphorization as an object. For example:

"The day wore away, and even through the twilight they could see the lone ivy leaf clinging to its stem against the wall"

(Fielding, 2005, pp. 630). 
The concept of time is anthropomorphically implemented in the work of Shakespeare named as: "Winter History". In this text time acts as a participant of the action and a monologue is conducted on its behalf. A text named as 'Richard II' by Shakespeare is a great example of a personification too. Time is making a human into a clock.

"...now hath time made me his numbering clock"

(Shakespeare, 2003, pp. 93).

There is another interesting property of time. That is relativity. It can be found in the example below:

"A summer's day will seem an hour but short",

"if the interim be but a sennight, Time's pace is so hard that it seems the length of seven year",

"the swift foot of Time",

"the lazy foot of Time" (Shakespeare, 2010, pp. 301).

The characters of Shakespearian literature have their own subjective understanding of time. They interact with time individually. Some of them cherish time, others perceives time as something negative. For example:

"O hateful, vaporous, and foggy Night!".

"So hallow'd and so gracious is the time".

"Time is the nurse and breeder of all good" (Shakespeare, 2010, pp. 115).

Archaic images of time can be found in Shakespeare's literature. As a rule they are historically related. Night time is perceived as something negative because in Old English period people believed that a night is a devilry time.

"Deep night, dark night, the silent of the night, The time of night when Troy was set on fire; The time when screech-owls cry and ban-dogs howl, And spirits walk and ghosts break up their graves, That time best fits the work we have in hand" (Shakespeare, 2010, pp. 408).

A night in 'Hamlet' by Shakespeare is named as 'witches' time' and once again perceives as evil and horrifying. Although in his another text 
'A Midsummer Night's Dream' he, on the contrary, claims that night time is positive time and it belongs to elves. The analysis of the Shakespeare's literary works caused a selection of the basic features of the TIME concept in literature discourse. A large number of circumstances influenced an understanding of the TIME concept and its implementation in literature texts. The Early English period is a period of the final semantic nomination of the TIME concept in the English-speaking environment. Many temporal lexemes had been added to English language through borrowing from Latin and Greek languages. Various time relations started to be lexically marked by using of such Latin prefixes as: "re-", “inter-", “ante-", "pre-", "post-".

Metaphorization of the TIME concept might be conducted by using phraseological units with a time component. In this case it results to the formation of different lexical-semantic groups. The first group is named as 'a realization of anything in the proper moment'. Next examples are referring to that group.

"I put it in good time" (Steinbeck, 2002, pp. 29).

"...I tell you in good time to keep clear of $m e$ "

(Dickens, 2003, pp. 456).

The phraseological group 'untimeliness' is related to the concept of time. At the linguistic level it can be represented by such lexical units as: "time", "day", "years", "hour", "behind", "ahead of”, "out of", "after", "before”, "beyond”. For instance:

"I have fallen behind the time, and am too old to catch it again" (Dickens, 2003, pp. 135).

A lexico-semantic group 'waiting time' is represented on the linguistic level by such phrases and word-combinations as: "to bide one's time"; "to play for time"; "to take one's time over smth."; "to spar for time"; "to bear the test of time"; "time hangs heavily on smb's hands"; "time works wonders". For example:

"Mr. Brown tried to gain time so he kept silence" "You bide your time. You get away from me" (Steinbeck, 2002, pp. 51).

A lexico-semantic group named as 'period of time limited by the positive or negative moment' is actualized by such phrases and word-combinations 
as: "one's time is up"; "one's time has come"; "have had one's days"; "close one's days"; "one's days are numbered"; "be hard pressed for time", "of a day", "of the moment"; "for a time"; "it will last one's time"; "one's time is up"; "one's time has come". It might be seen in the text fragment:

"The club which old Jolyon entered ... was one of those political institutions of the upper-middle class which have seen better days" (Galsworthy, 2001, pp. 223).

A lexico-semantic group 'behavioral characteristic' has got emotional positive or negative features.

"You just made time with me" (Steinbeck, 2002, pp. 33).

A lexico-semantic group named as 'time characteristic' is linguistically represented by these word-combinations: "salad days"; "palmy days"; "better days"; "red- letter day"; "daft days"; "presidential year"; "the good old times"; "golden times"; "troublous times"; "black-letter day"; "fall on evil days"; "a rainy day (dark days)"; "a bad quarter of an hour"; "dark hour"; "dead hours"; "rush hours"; "black Monday"; "white night"; "hard times"; "all Fool's day"; "every day is not Sunday"; "dog days"; "at dead of night”, for example:

“...both his clothes and his general air had indicated a period of better days for him" (Dreiser, 2000, pp. 508).

A lexico-semantic group named as 'definite time period' is represented linguistically by such phrases: "at a time"; "at one time"; "at the best of times"; "at one's time of life"; "from time immemorial"; "up to this time"; "in all one's born days"; "between two days"; "at the present day"; "in the days of old"; "in these latter day"; "at dawn (at day)"; "in a moment"; "at the best of times"; "from time immemorial"; "in all one's born days"; "at the present day"; "in the days of old"; "in these latter day"; "all day long"; "lay days"; "the other day"; "the small hours"; "tender years"; "at one time"; "at one's time of life"; "in all one's born days". For instance:

"At one time I talked to him about her, 'cause he reads so much stuff"' (Steinbeck, 2002, pp. 82).

Next example is a demonstration of the Present Tense category objectification. It happens due to the using of the verb 'shed' and the adverb 'now' 
"Now the orchards in full blow

Shed their petals white as snow" (Carman, B. W.).

In a literature text an author might represent Present Tense in a very peculiar manner that a reader would be encouraged to find some information in the past textual time, for instance:

"Ah, we disparage still / The Tidings of Good Will, / Discrediting

Love's gospel now as then!" (Carman, B. W.).

This example is a demonstration of a certain event that happened in the past and continuous in the present.

In certain fragments of literature texts one can find the simultaneous functioning of all kinds of time, for example:

"When Frank plays his horn / it's like yesterday never happened / or tomorrow doesn't need thinking about" (Canadian Poetry Online).

The key lexical unit in the example above is 'tomorrow'. According to this a special potential ability for events realization appears in the text. And these kinds of events are existing in the character's mind at the moment.

The main basis of a syntactic semantics is a proposal that simulates the extra-language situation. The proposal is a formal logical structure which includes the predicate and the arguments attached by it. Such arguments are linked by semantic roles (certain content relationships). There are some semantic roles (cases): agentive, dative, instrumentalise, factitive, objective, locative. These cases are universal by nature and consistent with the various ways of their basic realization in a particular language.

The agentive case means a living initiator of an action. Linguistically it realizes by the verb.

"Time was behaving in a more peculiar fashion than ever"

(Rowling, 2002, pp. 431).

The objective case is semantically neutral and it is represented by the noun. The noun's function depends on the verb semantics.

"Now, if you only kept on good terms with him <Time>, he'd do almost anything you liked with the clock" (Carroll, 2000, pp. 89).

The dative case or experiencer means a living being. The state on the living being was broke by an action or a situation which is expressed by the verb. 
"Children, Time is dead; now is the beginning of knowledge"

(Haggard, 2007, pp. 136).

There are situations when a time movement is associated with a bird that's able to fly or drop its feathers.

"Time shall moult away his wings" (Suckling, 2008, pp. 110).

The factitive case or resultative means a creature or a subject which appears as a result of actions or situations expressed by the verb.

"Oh, instant of time born to colour all eternity to thine own hue" (Haggard, 2007, pp. 155).

The locative case means an action or space orientation of a situation or an action expressed by the verb.

"And travel through time as through a country filled with many wild and empty wastes" (Addison, 2006 pp. 81).

The instrumentalise case means strength or a non-living subject. They are caused by an action expressed by the verb.

"It was an old woman, tall and shapely still, though withered by time" (Dickens, 2003, pp. 201).

There are prepositions which classified by the agentic / non-agentic feature. It's been made in order to understand time properties and in order to find correlation between the TIME concept and other aspects of the textual reality.

The analysis of the chosen material has led to the distinction of five predicate groups such as: activity, location, status, quality and process. The activity is represented as an agentic situation in progress. The agent is a personified time, person or some phenomenon of the outside world. They might be represented by the dative: agentive - the predicate of change - dative - resultative. Next situations are the examples of this representation.

The first variation actualizes when a certain subject or person shows or acquires other qualities due to the action of time:

"It may be withering to know that ere the hand of Time had made me much less slim than formerly and dreadfully red on the slightest exertion..." (Dickens, 2016, pp. 211). 
The second variation actualizes when a certain subject or person is being changed due to the action of time:

"The mine which Time has slowly dug beneath familiar objects is sprung in an instant; and what was rock before, becomes but sand and dust" (Dickens, 2018, pp. 637).

The third variation actualizes when a certain subject or person has been moved due to time:

"Time hustled him into a little noisy and rather dirty machinery

and made him Member of Parliament for Coketown"

(Dickens, 2003, pp. 167).

The instantaneous agentive situation is "location". Personified time acts as an agentive: an agentive - a predicate of location - a locative. In this case, two proposals had been found.

The first one actualizes when a certain subject, person, or circumstance is the point in the direction to which the time moves.

"Tonight at midnight. The time is drawing near"

(Dickens, 1999, pp. 36).

The second one actualizes when time acquires such characteristics, as if it is placed in a certain capacity.

"Time is up"

"Time is out" (JOURNAL ARTICLE, 2000).

These prepositions might be used for description of the person's location in time. It should be noted that in this case the structure loses the status of agentiveness. According to this the proposition has the following form: dative - location predicate - objective. In this case, a particular subject or person is placed in time.

"The frail bridge of time on which we tread sinks back into eternity at every step we take" (Jerome, 2005, pp. 23).

Personified time from the "state" and "quality" groups is represented as a dative. The non-agentive situation is "quality" and it is interpreted as the ongoing quality of the subject. According to this a following structure forms: 
dative - a predicate of similarity - an objective or a result. Such a proposal can be divided into the following ones:

The proposal actualizes when the time acquires a similarity feature:

"Time jump like a broken typewriter" (Burroughs, 2004, pp. 108).

The proposal actualizes when the time repeats some actions of a certain subject or person.

"And time could only tutor us to eke our rapture's warmth with custom's afterglow" (London, 2007, pp. 49).

Next distinguished structure has such form as: objective - location predicate - locative. The objective is represented by special features of the English linguo-culture. The locative is represented by the figurative description of the time. The actualization of these proposals is shown below.

The proposal actualizes when a certain subject or person is created by the time:

"Out of the black cave of time, terrible and swathed in scarlet, rose the image of his sin" (Wilde, 2008, pp. 166).

Next preposition group is characterized by the objective as the time and a person as the dative. The form of this group includes: dative - a predicate of similarity - objective. This preposition actualizes when certain properties of the time exists by analogy.

"Their officers were equipped, like the figure of Time, with an hourglass in one hand, and a scythe in the other" (Addison, 2006 pp. 87).

Next structure is modeling 'state' as an ongoing non-agentive situation. It has the following form: dative - a predicate of state - resultative. Three prepositions were distinguished in this structure.

The first one actualizes when a certain subject or person is on the same level with the time:

"The days sported by us, as if Time had not grown up himself yet,

but were a child too, and always at play" (Dickens, 2004, pp. 674).

The second one actualizes when a certain subject or person become characteristic for the time:

"On her beauty there has fallen a heavier shade than Time of his unassisted self can cast, all-potent as he is" (Dickens, 2003, pp. 466). 
The third one actualizes as a process when a 'time' lexeme could not be found in a sentence. In that case the secondary nomination of the TIME concept is used instead:

"With such people the grey head is but the impression of the old fellow's hand in giving them his blessing, and every wrinkle but a notch in the quiet calendar of a well-spent life" (Dickens, 2003, pp. 511).

Next group named as 'process' is characterized by the ongoing agentive situation. In this case the agentive is represented as a person who manipulates time. The person perceives with the role of dative or objective. This kind of situation has the following form: agentive - a predicate of action - dative or objective. The proposals of this situation have different variations.

The first variation actualizes when there is a reason for a subject or person to be in dependence from the time:

"Leave all else to time, truth, and steadfastness" (Dickens, 2006, pp. 497).

The second variation actualizes when a certain subject or person manipulates time:

"It is vastly wonderful for so stupid a clod to bestride the shoulders of time and ride the eternities" (London, 2018, pp. 33).

Next structure has such construction as: agentive - a predicate of using - dative (time) - resutative. There are some prepositions of the structure.

The preposition actualizes when the time is used by one person to explain something to other one:

"I'd like time to tell you about it" (Fitzgerald, 1995 pp. 67).

\section{Conclusions}

Specific metaphor properties are the reason why a very important role in a language is dedicated to the metaphor. Language embodiment of new concepts and a creation of new linguistic manners is a direct consequence of the metaphorization process. Certain linguistic forms are a place of a realization of cognitive reality images. These images are based on a metaphorical transference. 
The development of the TIME concept part named as time calculation had started in early English period (XIV - XV centuries). The TIME concept has been metaphorically realized very differently. The metaphorization depends on the period of the English history. Modern metaphorical realization of the TIME concept has changed many times but the basic metaphorical associations remained non-deformed.

There are prepositions which classified by the agentic / non-agentic feature. It's been made in order to understand time properties and in order to find correlation between the TIME concept and other aspects of the textual reality. The analysis of the chosen material has led to the distinction of five predicate groups such as: activity, location, status, quality and process. The classification of the prepositions was made in the research. They were distinguished according to the predicates. As a result models of the TIME concept description have been made. It proofs the fact that the TIME concept might be realized as the agentive, objective and dative. The using of the 'time' lexeme as a living initiator of the action (agentic) is syntactically reasoned. This action causes the personification of time in the English culture.

\section{References}

Addison Joseph (2006) Essays and Tales. / Dodo Press, p.128. ISBN 9781406505191.

Adger, D. (2002) Core Syntax. A Minimalist Approach. Oxford: Oxford. University Press, p. 349. ISBN 9780199243709.

Anikina, A.B. (2005) Obraznoye slovo v khudozhestvennom i publitsisticheskom proizvedenii. Voprosy stilistiki teksta [The abstract word in the literature text. The questions of the text stylistics]. Moscow, p. 216.

Arutyunova, N.(1990). Metafora i diskurs: Vstup. stat'ya. [A metaphor and a discourse: an introductory article]. Moscow: Progress. p. 362.

Batsevych, F. (2009). Dukhovna synerhetyka ridnoyi movy: Linhvofilosofs'ki narysy: Monohrafiya. [Spiritual synergy of native language: Linguistic philosophical essays: Monograph]. Kyiv: VTs “Akademiya”, P. 192.

British National Corpus [Электронный ресурс]. - Режим доступа: http://corpus. byu.edu/bnc/

Burroughs S. William (2004) Naked Lunch. / Grove/Atlantic, p. 289. 
Canadian Poetry Online [Електронний pecypc]. - Режим доступу: http://www. library.utoronto.ca/canpoetry/index_poet.htm.

Carman, B. W. “119 poems” [Електронний ресурc]. -http://www.poemhunter.com/i/ebooks/pdf/bliss_william_carman_2012_7.pdf. (access date 20.05.2019).

Carroll Lewis (2000) Alice's Adventures in Wonderland \& Through the Looking-Glass. / Penguin Group (USA), p.239. ISBN 9780451527745.

Choyce, L. “Caution to the Wind” [Електронний ресурc]. - Режим доступу: http:// www.lesleychoyce.com// (Access date 20.05.2019).

Cocker, E. Cocker's Arithmetick. Printed for Mess. Bettesworth and Hitch, at the Redlyon in Pater-noster row; R. Ware, at the Sun and Bible in Amen-corner; and J. Hodges, at the Looking-glass on London-bridge, 1736. 183 p.

Corpus of Middle English Prose and Verse. University of Michigan. URL: http:// quod.lib.umich.edu/c/cme/ (access date 20.04.2016)

Davies, Mark. (2008-) The Corpus of Contemporary American English (COCA): 560 million words, 1990-present. Available online at https://corpus.byu.edu/coca/. (access date 20.04.2016).

Dickens Charles (1999) A Christmas Carol. / Bethany House Publishers, p. 104.

Dickens Charles (2003a) Barnaby Rudge. London : Penguin Books, p. 744.

Dickens Charles (2003b) Dombey and Son. / Modern Library, p. 880.

Dickens Charles (2003c), Hard Times. London : Pearson Longman, p. 353.

Dickens Charles (2003d), Oliver Twist. London : Penguin Books, p. 608.

Dickens Charles (2004) David Copperfield. London : Penguin , p. 882.

Dickens Charles (2006) Bleak House. London : Penguin Books, p. 1017.

Dickens Charles (2016) Charles Dickens: Little Dorrit. / CreateSpace Independent Publishing Platform, p. 360.

Dickens Charles (2018) The Life and Adventures of Martin Chuzzlewit. / Createspace Independent Publishing Platform, p. 816.

Dreiser Theodore (2000) An American Tragedy. / Signet Classics, p. 859.

Fielding Henry, Keymer Thomas (Editor), Wakely Alice (Editor) (2005) The History of Tom Jones, a Foundling. London : Penguin Books. p. 975.

Fitzgerald F. Scott (1995) The Love of the Last Tycoon. / Scribner, p. 169.

Galsworthy John (2001) The Man of Property / Wordsworth Editions Ltd. p. 364.

Haggard H. Rider (2007) Dawn. / BiblioLife, p.512. 
Jerome K. Jerome (2005) Idle Thoughts of an Idle Fellow. / MONDIAL, p.95.

Johnson S. A Dictionary of the English Language. 1755. URL: http://johnsonsdictionaryonline.com/ (access date 20.04.2016).

JOURNAL ARTICLE : The early Renaissance personification of Time and changing concepts of temporality. S. Cohen / Renaissance Studies Vol. 14, No. 3 (SEPTEMBER 2000), pp. 301-328 / Published by: Wiley https://www.jstor.org/stable/24412870 / Page Count: 28

Karpilovs'ka, Ye. (2010).Vtoryna nominatsiya u suchasniy ukrayins'kiy movi: tendentsiyi rozvytku. [The secondary nomination in the modern Ukrainian language: development trends]. Linhvistychni studiyi. Ed. 20. pp. 27-32.

Kravets', L. (2012). Dynamika metafory v ukrayins'kiy poeziyi XXst.: monohrafiya. [Dynamics of metaphor in Ukrainian poetry of the twentieth century: monograph]. Kyiv: VTs «Akademiya», p. 416.

Kytö, M., Walker, T.M. A Corpus of English Dialogues 1560 1760. URL: https://www. sketchengine.co.uk/corpus-english-dialogues/ (access date 20.04.2016).

Lesyn, V., Pulynets', O. (1982). Slovnyk literaturoznavchykh terminiv. [Dictionary of the literary terms]. Kyiv: Rad. shkola, p. 486.

Levitskiy, V. (2007). Kvantitativnyye metody v lingvistike. [Quantitative methods in linguistics]. Vinnitsa: Nova Kniga. p. 264.

Literaturnaya entsiklopediya [Literature encyclopedia]: web-site: URL: http://feb-web. $\mathrm{ru} / \mathrm{feb} / \mathrm{mas} / \mathrm{mas}-\mathrm{abc} /$ default.asp (access date 02.06.2018)

London Jack (2007) When God Laughs and Other Stories. / 1st World Library, p.180.

London Jack (2018) John Barleycorn. / CreateSpace Independent Publishing Platform, p.90.

Nelyubin, L. (2003). Tolkovyy perevodovedcheskiy slovar'. [Dictionary for translators]. Moscow: Flinta: Nauka. p. 320.

Rowling J.K., Grand Pré Mary (Illustrator) (2002) Harry Potter and the Goblet of Fire. / Scholastic , p. 734.

Rusanivs'kyy, V., Taranenko, O. (2004).Ukrayins'ka mova: Entsyklopediya. [Ukrainian language: encyclopedia]. Kyiv: Ukr. entsykl. im. M.P. Bazhana, p. 824.

Shadwell, Th. The Lancashire Witches, and Tegue O Divelly the Irish Priest. A Comedy, Etc. J. J. \& P. Knapton, 1736, p. 108.

Shevchenko, L. (2010). Slovnyk ukrayins'koyi movy. V 20 tomakh. [Ukrainian dictionary. In 20 volumes]. Vol. 11, Kyiv: Naukova dumka. p. 694. 
Steinbeck John (2002) Of Mice and Men. London : Penguin Books, p. 112.

Suckling John (2008) The Poems of Sir John Suckling. / BiblioLife, p.264.

Swift, J. The Journal Of a Modern Lady // Aikin J. Select Works of the British Poets: In a Chronological Series from Ben Jonson to Beattie. T. Wardle, 1840, p. 807.

Teliya, V. (1988). Metafora $v$ yazyke i tekste. [The metaphor in the language and text]. Moscow: Nauka, p. 176.

Wilde Oscar, The Picture of Dorian Gray London: Penguin Books Ltd 2008, p. 304.

William Shakespeare (1988) The Poems. NY : Bantam Classics, p. 528.

William Shakespeare (2003) Richard II. Oxford : Oxford University Press, p. 168.

William Shakespeare (2010) The Complete Works of William Shakespeare. NY: Barnes \& Noble Inc, p.1264.

Yaremenko, V., Slipushko, O. (1999). Novyy tlumachnyy slovnyk ukrayins'koyi movy: U 4 t. [New Explanatory Dictionary of the Ukrainian Language: in 4 vol]. Vol. 2. Kyiv: AKONIT, p. 912.

Yeshchenko, T. (2001). Metafora v ukrayins'kiy poeziyi 90-kh rokiv xx stolittya. [A metaphor in the Ukrainian poetry of $90^{\text {th }}$ years of the XX century]. Donets'k: Donets'kyy natsional'nyy un-t., p. 337.

Zaliznyak, A. (2006). Mnogoznachnost'v yazyke i sposoby eyë predstavleniya. [Multivaluedness in the language and ways to represent it]. Moscow: Yazyki slavyan. Kul'tur, p. 672. 
